\title{
A “BANALIDADE DO MAL" NAS EMPRESAS: REVISITANDO HANNAH ARENDT
}

\author{
THE "BANALITY OF EVIL" IN BUSINESS: \\ REVISITING HANNAH ARENDT
}

\author{
LA "BANALIDAD DEL MAL" EN LAS EMPRESAS: \\ REVISANDO A HANNAH ARENDT
}

\author{
NATERCIA SAMPAIO SIQUEIRA \\ https://orcid.org/0000-0002-7495-147X / http://lattes.cnpq.br/8860525584040414 / naterciasiqueira@yahoo.com.br \\ Universidade de Fortaleza - UNIFOR. \\ Fortaleza, CE, Brasil.
}

$\begin{aligned} \text { https://orcid.org/0000-0001-8443-6415 / http://lattes.cnpq.br/7735673221169665 } & \begin{array}{r}\text { CAROLINE VIRIATO MEMÓRIA } \\ \text { Universidade de Fortaleza - UNIFOR. } \\ \text { Fortaleza, CE, Brasil. }\end{array}\end{aligned}$

\begin{abstract}
RESUMO
Por meio de pesquisa qualitativa, exploratória e bibliográfica, levanta-se referencial teórico sobre assédio moral, e observa-se a predominância de associar o seu cometimento nas empresas a pessoas com perfil psíquico perverso. É este o dado que se pretende questionar, o que se faz a partir de conceitos talhados por Hannah Arendt, tais como a "banalidade do mal", que ela se utiliza na obra "Eichmann em Jerusalém: um relato sobre a banalidade do mal". Para Hannah Arendt, em nome de cumprir ordens, Otto Adolf Eichmann contribui para o funcionamento da máquina nazista. Dessa obra, é apropriada a ideia de ausência de pensamento e de ambição para identificar o assédio moral nas empresas, propondo-se o entendimento de que a personalidade do assediador não o caracteriza; antes, o assédio pode se manifestar numa cultura empresarial acrítica. Para chegar à referida conclusão, no primeiro tópico são analisados aspectos relacionados ao assédio moral nas empresas, e no segundo, trata-se do conceito da "banalidade do mal” para, ao final, argumentar em favor de sua aplicação para identificação do assédio moral no trabalho.
\end{abstract}

Palavras-chave: Assédio moral nas empresas; perfil do assediador; "banalidade do mal”.

\begin{abstract}
Through qualitative, exploratory and bibliographical research, a theoretical reference is made on moral harassment, and the predominance of associating their commitment in the companies to people with perverse psychic profile is observed. This is the point to be drawn from Hannah Arendt's concepts, such as the "banality of evil", which is used in the work "Eichmann in Jerusalem: a story of the banality of evil". For Hannah Arendt, in the name of fulfilling orders, Otto Adolf Eichmann contributes to the functioning of the Nazi machine. From this work, the idea of lack of thought and ambition to identify moral harassment in companies is appropriated, proposing the understanding that the personality of the harasser does not necessarily characterize him; rather, harassment can manifest itself in an uncritical business culture. To reach this conclusion, in the first topic, aspects related to moral harassment in companies are analyzed, and in the second, it is the concept of "banality of evil" in order to argue in favor of its application to the identification of moral harassment in the work environment.
\end{abstract}

Keywords: Moral harassment in companies; aggressor profile; "banality of evil".

\section{RESUMEN}

A través de la investigación cualitativa, exploratoria y bibliográfica, se hace una referencia teórica sobre el acoso moral, y se observa el predominio de asociar su compromiso en las empresas con personas con perfil psíquico perverso. Este es el punto que debe extraerse de los conceptos de Hannah Arendt, como la "banalidad del mal", que 
se utiliza en la obra "Eichmann en Jerusalén: una historia de la banalidad del mal". Para Hannah Arendt, en nombre de cumplir órdenes, Otto Adolf Eichmann contribuye al funcionamiento de la máquina nazi. A partir de este trabajo, se apropia la idea de falta de pensamiento y ambición para identificar el acoso moral en las empresas, proponiendo el entendimiento de que la personalidad del acosador no necesariamente lo caracteriza; más bien, el acoso puede manifestarse en una cultura empresarial no crítica. Para llegar a esta conclusión, en el primer tema se analizan aspectos relacionados con el acoso moral en las empresas, y en el segundo tema se estudia el concepto de "banalidad del mal" y se propone su aplicación en la identificación del acoso moral en el entorno laboral.

Palabras clave: Acoso moral en las empresas; perfil de agresor; "banalidad del mal".

\section{SUMÁRIO}

INTRODUÇAO; 10 ASSÉDIO MORAL NAS EMPRESAS; 2 A “BANALIDADE DO MAL" E O ASSÉDIO MORAL NAS EMPRESAS; CONCLUSÃO; REFERÊNCIAS.

\section{INTRODUÇÃO}

Diante da complexidade das relações interpessoais, quer no âmbito familiar ou, especificamente, no trabalho, em que há uma relação desigual de poder, repercute o assédio moral, que não é um fenômeno novo. Porém, somente a partir dos anos 80 tem sido abordado, principalmente nos Estados Unidos da América e em alguns países da Europa, onde Heinz Leymann, pesquisador em Psicologia do Trabalho, iniciou os estudos acerca de assédio moral nas relações de trabalho.

0 assédio moral é uma agressão que causa graves impactos à saúde física e psíquica do assediado, razão pela qual preocupa toda a sociedade e se o deve estudar nas suas diversas manifestações, mas com maior atenção aos casos menos evidentes. De outra sorte, embora o assédio moral não seja exclusividade das relações de trabalho, e nem seja o único tipo de abuso praticado em decorrência da relação de emprego, o recorte teórico realizado na pesquisa o foca no âmbito das empresas, haja vista ser inegável que aspectos como a subordinação jurídica e a hipossuficiência do trabalhador os torna ainda mais recorrente no meio laboral.

Uma primeira abordagem do tema se faz através de estudos de intelectuais já largamente reconhecidos, como Marie-France Hirigoyen, para quem o assédio moral nas relações trabalhistas é "qualquer conduta abusiva, manifestando-se, sobretudo por comportamentos, palavras, atos, gestos, escritos que possam trazer dano à personalidade, à dignidade ou à integridade física ou psíquica de uma pessoa, pôr em perigo seu emprego ou degradar o ambiente de trabalho"1.

\footnotetext{
${ }^{1}$ HIRIGOYEN, Marie-France. Assédio moral: a violência perversa no cotidiano. Rio de Janeiro: Bertrand Brasil, 2002, p. 65.
} 
Desse e de outros conceitos, observa-se que o assédio moral é caracterizado, preferencialmente, pela natureza psicológica da agressão, que atenta contra a dignidade psíquica do indivíduo. Já no Brasil, os primeiros nomes que se destacaram no estudo do assédio moral no meio ambiente do trabalho foram Márcia Novaes Guedes e Margarida Maria Silveira Barreto.

Indo além na pesquisa, realiza-se o levantamento bibliográfico em livros e no Portal de Periódicos da Coordenação de Aperfeiçoamento de Pessoal de Nível Superior - CAPES mediante a utilização dos descritores "assédio moral" e "perfil do assediador moral”, tanto em português, como em inglês, em resultado do qual se constata a predominância de registros que qualificam a personalidade do agressor como perversa, devido ao fato de agir comumente de maneira atentatória à dignidade psíquica do indivíduo, o que afeta o seu equilíbrio emocional.

Em suma, a subjetividade do dano e da agressão é dado que se revela fortemente presente na conceituação de assédio moral. Não obstante, o assédio é um elemento da realidade, de maneira que não se mostra suscetível de ser cristalizado em um conceito, mesmo que jurídico.

É necessário que se continue a observá-lo, em especial quando se constata a crescente tolerância, complacência e banalização, até em escala de estratégia de gestão empresarial, de diferentes formas de assédio, que podem minar a capacidade laboral e a saúde física e psíquica do trabalhador. Neste presente estudo, por conseguinte, se propõe um olhar para a outra face do assédio moral que, embora pouco divulgada e ainda não muito estudada, pode ser avassaladora: o mal praticado por aqueles que, segundo Hannah Arendt, agem de forma acrítica e coisificam o outro e a si (o que ela chama de "banalidade do mal").

Já no contexto histórico que Arendt se utiliza para fazer as suas considerações, os Estados totalitários da Segunda Guerra, se pode identificar o assédio moral em relações laborais, qualificado pela banalidade do mal, na frase alemã, cunhada na entrada do campo de concentração de Auschwitz, “Arbeit Macht Frei”, que em português significa "o trabalho liberta". Essa era a última esperança que os judeus tinham antes da morte em câmaras de gás ou em trabalhos forçados.

Mas Arendt não limita sua obra à questão do nazismo, do totalitarismo e da política. Ela aborda o trabalho na obra "Condição humana", quando denuncia a ausência da vida ativa característica da engrenagem de produção e consumo que mastiga a pessoalidade humana. No mundo capitalista, uma vez que o trabalho e o status pelo consumo diferenciam e dignificam a 
pessoa aos olhos próprios e dos demais, as pressões corporativas corroem a perspectiva do humanamente aceitável, mediante fixação de metas que não respeitam a pessoalidade humana.

A obra de Hannah Arendt, seus conceitos e categorias inovadores, permite que se estude não apenas a política, mas diversas áreas do pensamento e ação humana, tais como ética, psicologia, Direito. E no caso em questão, a utilização da obra de Arendt mostra-se bastante útil para se identificar um tipo de assédio moral asséptico, que não se encontra suficientemente explorado pela literatura e que nem o é facilmente identificado na prática: o assédio moral impessoal, que dispensa a perversidade do agente e que, muitas vezes, se infiltra e se sedimenta como normal estratégia trabalhista empresarial.

Para a referida análise, foi realizada pesquisa bibliográfica, exploratória, descritiva, de natureza qualitativa, por meio de consulta a livros, periódicos, sítios eletrônicos, leis e Constituição Federal. Na primeira parte do estudo, é analisado o assédio moral no trabalho, com destaque para aspectos como: a violação à dignidade do trabalhador, o abuso do poder diretivo, a intencionalidade do agressor, a possibilidade de reparação por danos morais, os elementos caracterizadores do assédio moral, a sua conceituação e o perfil do assediador. Na segunda parte, revisita-se o pensamento de Hannah Arendt, em especial sobre a "banalidade do mal", para, a seguir, aplicá-lo às relações laborais no âmbito de empresas, com o propósito de oferecer o perfil de um tipo de assediador pouco considerado pelos registros teóricos: que é o agressor que, ao cumprir ordens sem refletir de forma crítica acerca do que faz, também provoca assédio moral no meio ambiente laboral.

\section{ASSÉDIO MORAL NAS EMPRESAS}

As relações de trabalho são também relações de poder, e não apenas relações de produção. Segundo Zygmunt Bauman², a modernidade vive uma nova fase, a da liquidez, fluidez, em que as instituições tiveram as alavancas morais quebradas ou enfraquecidas, o que gerou o fim do engajamento mútuo, com impactos nas condições humanas e, principalmente, na concepção do trabalho.

Nas palavras de Candy Florencio Thome ${ }^{3}$, no neoliberalismo, a violência moral é considerada banal e complementa ao afirmar que neste contexto se tem o fomento da banalidade do mal por se criar a falsa ideia de que a violência no trabalho é um dado sem volta,

\footnotetext{
2 BAUMAN, Zygmunt. Modernidade líquida. Rio de Janeiro: Jorge Zahar Editor, 2000, p. 11-18.

3 THOME, Candy Florencio. 0 assédio moral nas relações de emprego. São Paulo: LTr, 2009, p. 26.
} 
contra o qual não se pode lutar. Logo, o sofrimento relacionado ao trabalho é utilizado para perpetuar relações de poder.

O ser humano é então considerado um fator de produção, inserido em uma organização empresarial que o submete ao poder hierárquico do empregador, que se divide em poder diretivo, poder disciplinar e poder regulamentar. 0 poder diretivo, para Leda Maria Messias da Silva ${ }^{4}$, consiste na faculdade de o empregador dirigir pessoalmente a prestação de serviços de seus empregados que the são contratualmente subordinados.

Sobre o tema, Thome ${ }^{5}$ pondera que o poder de comando não é absoluto e pode haver abuso do poder diretivo quando o empregado, temendo o desemprego, submete-se a pressões ou humilhações do chefe. Inclusive, conforme José Afonso Dallegrave Neto ${ }^{6}$, o assédio moral decorrente da relação de emprego enseja justa causa do empregador.

Grande parte das situações em que há excesso no exercício do poder diretivo pode caracterizar assédio moral, que debilita a dignidade humana do trabalhador assediado. Nessa perspectiva, Margarida Barreto e Roberto Heloani avaliam que:

é necessário compreendermos não apenas as mudanças que ocorrem nos espaços do mundo do trabalho, mas como se estabelecem as relações de produção, como vivem e adoecem os diferentes grupos hierárquicos dentro do espaço fabril e, quais os valores e crenças que perpassam cada grupo socioeconômico, qual a práxis social desses distintos grupos dentro da empresa. ${ }^{7}$

Nesse contexto, o poder diretivo do empregador não é ilimitado, devendo observância aos parâmetros fixados pelo ordenamento jurídico e à dignidade da pessoa humana, a qual, na definição de Ingo Wolfgang Sarlet ${ }^{8}$, é a qualidade intrínseca e distintiva de cada ser humano, que o faz merecedor do mesmo respeito e consideração por parte do Estado e da comunidade. A implicar, por conseguinte, um complexo de direitos e deveres fundamentais que assegurem à pessoa proteção contra todo e qualquer ato de cunho degradante e desumano.

\footnotetext{
4 SILVA, Leda Maria Messias da. Poder diretivo do empregador, emprego decente e direitos da personalidade. Revista Jurídica Cesumar, v. 1, n. 6, p. 267-281, 2006, p. 271.

${ }^{5}$ THOME, Candy Florencio. 0 assédio moral nas relações de emprego. São Paulo: LTr, 2009, p. 136.

${ }^{6}$ DALLEGRAVE NETO, José Afonso. Responsabilidade civil no direito do trabalho. São Paulo: LTr, 2005, p. 236-237.

7 BARRETO, Margarida; HELOANI, Roberto. Violência, saúde e trabalho: a intolerância e o assédio moral nas relações laborais. Serv. Soc. Soc., São Paulo, v. 123, n. 1, jul./set. 2015, p. 554.

${ }^{8}$ SARLET, Ingo Wolfgang. A eficácia dos direitos fundamentais. Porto Alegre: Livraria do Advogado, 2001, p. 60.
} 
Além do assédio moral individual nas empresas, Guilherme Augusto Cardoso e Victor Hugo de Almeida ${ }^{9}$ lançam o olhar para o assédio moral na administração pública, por entender que, em seu âmbito, o trabalho guarda diversas características que contribuem para a ocorrência do assédio moral, com destaque para o fato de os cargos de chefia serem de nomeação essencialmente política (cargos em comissão, de livre nomeação e exoneração).

Nessa perspectiva, os autores enfatizam que "a inexperiência na gestão de pessoas e a ausência de previsão de qualificação técnica do comissionado podem ser fatores, portanto, que geram maior facilidade à prática de assédio moral no âmbito da administração pública”. Tanto mais, em razão de que a falta de estabilidade e a vinculação pessoal - mas não institucional comprometem o comissionado com políticas de gestão que não raro singram ou pela obtenção de elevada produtividade, ou pelo nepotismo, ou por ideologias políticas ou por propostas partidárias que afetam o bem estar físico e psíquico do trabalhador.

Por outro lado, os mesmos autores advertem sobre o paradoxo de a estabilidade do servidor estatuário também favorecer a ocorrência de assédio moral na administração pública, haja vista que o abuso é instrumento fracamente sindicável nas mãos do superior hierárquico insatisfeito, ocupante de cargo público.

O fato é que em ambas as situações, seja pelo comprometimento da empresa com altos índices de produtividade que as tornam receptivas à gestão trabalhista abusiva, seja pelo funcionamento viciado da máquina pública por políticas de nepotismo, por ideologias, por programas partidários ou mesmo por metas de produtividade infladas, de maneira a se mostrar o seu bom funcionamento perante a sociedade, a dignidade que, conforme anteriormente considerado, se revela na marca distintiva do ser humano, se revela fragilizada. 0 que, por sua vez, prejudica o elemento axiológico elementar às sociedades democráticas da contemporaneidade.

Seguindo a tendência do constitucionalismo contemporâneo, a Constituição Federal de $1988^{10}$ incorporou, expressamente, ao seu texto, o princípio da dignidade da pessoa humana (art. $1^{\circ}, \mathrm{III}$ ), definindo-o como fundamento da República. Mais adiante, a Constituição prevê no art. 170: "A ordem econômica, fundada na valorização do trabalho humano e na livre iniciativa, tem por fim assegurar a todos existência digna conforme ditames da justiça social”. Dessa

\footnotetext{
9 CARDOSO, Guilherme Augusto; ALMEIDA, Victor Hugo de. Assédio moral na administração pública: uma visão crítica da jurisprudência brasileira. Revista Eletrônica do Curso de Direito da UFSM, v. 11, n. 1, 2016, p. 332-333.

${ }_{10}$ BRASIL. Constituição Federal. Diário Oficial da República Federativa do Brasil, Brasília, 5 out. 1988. Disponível em: https://www.planalto.gov.br/ccivil_03/constituicao/constituicao.htm. Acesso em: 22 jan. 2018.
} 
forma, as atividades empresariais devem desenvolver-se sem se utilizar de estratégias que afrontem a dignidade do trabalhador, o que significa que deve ser evitada toda e qualquer possibilidade de assédio moral no ambiente laboral.

Como forma de proteção do trabalhador em sua dignidade, Dallegrave Neto ${ }^{11}$ dá relevo à possibilidade de reparação por danos decorrente de assédio moral no trabalho, por considerar como violação à dignidade do ser humano, e frisa que devem ser considerados na valoração de danos morais: o grau de culpa do ofensor, a dignidade da pessoa humana, a extensão e a gravidade do dano, a necessidade econômica da vítima e a capacidade econômica do agressor.

$\mathrm{Na}$ lição de Sebastião Geraldo de Oliveira ${ }^{12}$, ensina-se que, para configurar o dano moral, é dispensável provar o sofrimento da vítima, pois o autor entende que não há que se demonstrar aquilo que é ordinário e decorrente da própria natureza humana. Paulo Eduardo Vieira ${ }^{13}$ inova no entendimento relacionado à reparação desse tipo de dano, ao ponderar que, se o dano afetar a dignidade da pessoa humana, pouco importa se o ofendido sentiu, ou não, dor e sofrimento para ter direito à indenização. A dignidade seria assim protegida em uma dimensão objetiva.

Não obstante, o perfil do abusador ainda é tratado sob um caráter preponderantemente subjetivo. Para Maria Ester de Freitas ${ }^{14}$, "nas organizações, a violência e o assédio nascem do encontro entre a inveja do poder e a perversidade". Seguindo essa linha de raciocínio, Hádassa Dolores Bonilha Ferreira destaca que, para que se configure juridicamente o assédio moral, é preciso estar presentes os seguintes elementos:

a) A violação da dignidade do trabalhador por condutas abusivas desenvolvidas dentro do contexto profissional;

b) É um fenômeno portador de um risco invisível, porém com consequências concretas;

c) A intencionalidade do ato, elemento que se revela como resultado dessa perversidade, e que é verificado justamente pela repetição e duração no tempo das condutas abusivas;

d) Incapacidade do agente assediador em considerar os outros como seres humanos. Assim, a pessoa é tratada ou como uma coisa, ou como animal. 0 assediador viola o princípio da dignidade da pessoa humana;

e) Repetição da conduta assediadora;

11 DALLEGRAVE NETO, José Afonso. Responsabilidade civil no direito do trabalho. São Paulo: LTr, 2005, p. $145-241$.

12 OLIVEIRA, Sebastião Geraldo de. Indenizações por acidente do trabalho ou doença ocupacional. São Paulo: LTr, 2006, p. 262-263.

13 OLIVEIRA, Paulo Eduardo Vieira. O dano pessoal no trabalho. São Paulo: LTr, 2002, p. 237-238.

${ }^{14}$ FREITAS, Maria Ester de. Assédio moral e assédio sexual: faces do poder perverso nas organizações. ERA, v. 2, n. 41, abr./jun. 2001, p. 10. 
f) Prolongamento no tempo. ${ }^{15}$

Heinz Leymann" ${ }^{16}$ conceituou o fenômeno "afirmando que algumas características essenciais do assédio moral no trabalho são a confrontação e o constrangimento". Para Margarida Barreto ${ }^{17}$, a humilhação revela-se como uma das formas mais poderosas de violência nas relações organizacionais. Thomé ${ }^{18}$ vai além no estudo do tema ao pontuar que há casos em que o assédio moral já está num estágio tão agravado que pode chegar à violência física, até mesmo sexual, com o intuito de humilhar, sem realmente ter como objetivo a relação sexual.

A gravidade do problema relacionado ao assédio moral ganha densidade na obra de Hirigoyen ${ }^{19}$, que há muito tempo chama a atenção para o processo de destruição moral causado por esse tipo de assédio, que inclusive pode levar o agredido a desenvolver doença mental ou até à prática de suicídio. Nesse viés, Thomé ${ }^{20}$ afirma que as doenças decorrentes de assédio moral no trabalho mais comuns são: a depressão, o estresse e o suicídio.

Seguindo o mesmo raciocínio, Márcia Novaes Guedes assim conceitua assédio moral nas relações trabalhistas:

Todos aqueles atos comissivos ou omissivos, atitudes, gestos e comportamentos do patrão, da direção da empresa, de gerente, chefe, superior hierárquico ou dos colegas, que traduzem uma atitude de contínua e ostensiva perseguição que possa acarretar danos relevantes às condições físicas, psíquicas, morais e existenciais da vítima. ${ }^{21}$

Maria Ester de Freitas $^{22}$ também o define como uma conduta abusiva, intencional, frequente e repetida, que visa a diminuir, humilhar, vexar, constranger, desqualificar e demolir psiquicamente um indivíduo ou grupo, degradando suas condições de trabalho. Para Sara Maria

\footnotetext{
${ }^{15}$ FERREIRA, Hádassa Dolores Bonilha. Assédio moral nas relações de trabalho. Campinas: Russell, 2004, p. 43-45.

${ }^{16}$ LEYMANN, Heinz Apud THOMÉ, Candy Florencio. 0 assédio moral nas relações de emprego. São Paulo: LTr, 2009, p. 36.

17 BARRETO, Margarida. Violência, saúde e trabalho: uma jornada de humilhações. São Paulo: EDUC/FAPESP, 2003, p. 197.

18 THOMÉ, Candy Florencio. 0 assédio moral nas relações de emprego. São Paulo: LTr, 2009, p. 34.

19 HIRIGOYEN, Marie-France. Assédio moral: a violência perversa no cotidiano. Rio de Janeiro: Bertrand Brasil, 2002, p. 15.

${ }^{20}$ THOMÉ, Candy Florencio. O assédio moral nas relações de emprego. São Paulo: LTr, 2009, p. 79.

${ }^{21}$ GUEDES, Márcia Novaes. Terror psicológico no trabalho. São Paulo: LTr, 2004, p. 32.

${ }^{22}$ FREITAS, Maria Ester de. Quem paga a conta do assédio moral no trabalho?. RAE-eletrônica, v. 1, n. 6, jan./jun. 2007, p. 2.
} 
de Melo Elgenneni e Cristiane Vercesi ${ }^{23}$, a repetitividade e a intencionalidade são alguns dos elementos que caracterizam a ocorrência do assédio moral.

No mesmo sentido, Roberto Heloani ${ }^{24}$, entende que o assédio moral caracteriza-se pela intencionalidade. Outra voz que se junta a essas é a de Dallegrave Neto ${ }^{25}$, para quem o assédio moral só é admitido na forma dolosa, pois acredita que deve haver o objetivo de destruir emocionalmente a vítima.

Mas há também quem entenda de forma diferente. Conforme Débora Miriam Raab Glina e Lis Andreia Soboli ${ }^{26}$, a intencionalidade não pode ser considerada como um elemento essencial para a identificação do assédio moral.

Julyana Moreira Bortholo e Camila Oliveira da Rocha ${ }^{27}$ também contribuem para a compreensão do fenômeno ao relativizarem outro aspecto do conceito, quando afirmam que, embora um dos requisitos mais apontados por estudiosos para a caracterização do assédio moral seja a sua repetição, não há, todavia, como tomá-lo por elementar ao assédio, já que é possível vislumbrá-lo em atos isolados e até mesmo nas fases pré- contratual e pós-contratual. Segue esse raciocínio Jorge Luiz de Oliveira da Silva ${ }^{28}$ ao afirmar que os atos de assédio moral também podem se dar fora da jornada de trabalho, desde que ocorram em decorrência do labor.

Maria Ester de Freitas, Roberto Heloani e Margarida Barreto ${ }^{29}$ exploram ainda mais o conceito de assédio moral ao admitirem múltiplas formas para o fenômeno, não limitadas às posições ou relações formais de poder. Nessa perspectiva, Dirceu Pertuzatti e Maria de Lourdes Pinto Almeida ${ }^{30}$ entendem que o assédio moral na relação de emprego tem incidência na convivência entre empregado e empregador, em que se registra a ocorrência de um superior hierárquico sobre um subordinado, entre colegas de trabalho e do subordinado contra o superior

\footnotetext{
${ }^{23}$ ELGENNENI, Sara Maria de Melo; VERCESI, Cristiane. Assédio moral no trabalho: implicações individuais, organizacionais e sociais. Revista Psicologia: Organizações e Trabalho. Brasília, v. 1, n. 9, pp. 68-85, jan./jun. 2009, p. 73.

24 HELOANI, Roberto. Assédio Moral: um ensaio sobre a expropriação da dignidade no trabalho. RAEeletrônica, v. 1, n. 3, jan./jun. 2004, p. 5.

${ }_{25}$ DALLEGRAVE NETO, José Afonso. Responsabilidade civil no direito do trabalho. São Paulo: LTr, 2005, p. 235.

26 GLINA, Débora Miriam Raab; SOBOLL, Lis Andreia. Intervenções em assédio moral no trabalho: uma revisão da literatura". Revista Brasileira de Saúde Ocupacional. São Paulo, v. 126, n. 37, 2012, p. 270.

27 BORTHOLO, Julyana Moreira; ROCHA, Camila Oliveira da. Assédio moral nas relações de trabalho. Revista Terceiro Setor \& Gestão, v. 1, n. 9, 2015, p. 54.

${ }^{28}$ SILVA, Jorge Luiz de Oliveira da. Assédio moral no ambiente de trabalho. Rio de Janeiro: Editora e Livraria Jurídica do Rio de Janeiro, 2005, p. 12.

${ }^{29}$ FREITAS, Maria Ester de et al. Assédio Moral no Trabalho. São Paulo: Cengage Leaning, 2008, p. 34.

30 PERTUZATTI, Dirceu; ALMEIDA, Maria de Lourdes Pinto de. Assédio moral na relação de emprego no Brasil do século XXI: por um resgate da dignidade da pessoa humana. Revista da Faculdade de Direito UFPR, Curitiba, v. 1, n. 43, 2005, p. 4.
} 
hierárquico. Em direção semelhante se posicionam Sara Costa Benevides e Dayanna Gonçalves Rodrigues:

Não se deve confundir o perfil do assediador com o perfil de um chefe, pelo fato de este possui o poder de direção da atividade, no qual concentra o poder de organização, pois quem pratica o assédio nem sempre é o chefe, podendo ser um colega de trabalho, um subordinado ou um terceiro inserido no ambiente laboral. ${ }^{31}$

No entanto, convém destacar o que Hirigoyen ${ }^{32}$ ensina: “mesmo sem má-fé, todos nós podemos, em determinados contextos e diante de certas pessoas, adotar atitudes perversas". Então, segundo Pertuzatti e Almeida ${ }^{33}$, o assédio moral manifesta-se mediante atos perversos no ambiente de trabalho e a constatação do assédio moral no trabalho está relacionada aos requintes ardis que são peculiares do assédio moral.

Compartilham de pensamento similar Moraes et al. ${ }^{34}$, por entenderem que o assediador moral é uma pessoa extremamente calculista e cruel, que age mediante atitudes discriminatórias e perversas, com o fito único de excluir o trabalhador do ambiente de trabalho. Logo, os perfis ardiloso e perverso estão presentes de forma frequente na literatura do assédio moral trabalhista.

Mendonça et al. ${ }^{35}$ afirmam que o assediador moral normalmente escolhe sua vítima e a isola do grupo de trabalho, com inferiorização e desprezo. Rodrigo Goldschmidt e Jusara Crusaro $^{36}$ acreditam que normalmente os assediadores são pessoas vaidosas, levianas, dissimuladas, porém fracas e medrosas e, por esse motivo, tentam compensar suas fraquezas mediante o assédio moral aos colegas de trabalho.

\footnotetext{
31 BENEVIDES, Sara Costa; RODRIGUES, Dayanna Gonçalves. Assédio moral no ambiente de trabalho: uma análise sobre os malefícios causados à vítima e suas consequências, bem como a atuação da Lei n. 13.185, de 6 de novembro de 2015, que institui o Programa de Combate à Intimidação Sistemática (bullying). Revista Científica FAGOC - Jurídica, v. 2, n. 1, 2016, p. 44.

32 HIRIGOYEN, Marie-France. Mal-estar no trabalho: redefinindo o assédio moral. Rio de Janeiro: Bertrand Brasil, 2006, p. 247.

33 PERTUZATTI, Dirceu; ALMEIDA, Maria de Lourdes Pinto de. Assédio moral na relação de emprego no Brasil do século XXI: por um resgate da dignidade da pessoa humana. Revista da Faculdade de Direito UFPR, Curitiba, v. 1, n. 43, 2005, p. 8-12.

${ }^{34}$ MORAES, Patrícia Regina de Moraes et al. A Configuração do Assédio Moral nas Relações Trabalhistas. Revista Ampla de Gestão Empresarial, Registro, SP, v. 1, n. 3, abr. 2014, p. 206-209.

35 MENDONÇA, Gisele Galatti et al. Assédio Moral: Práticas coercitivas nas relações de trabalho. Revista Eletrônica de Ciências Empresariais, v. 2, n. 1, jan./jul. 2008, p. 7.

${ }^{36}$ GOLDSCHMIDT, Rodrigo; CRUSARO, Jusara. Assédio moral nas relações de trabalho. Pensar. Fortaleza, v. 1, n. 16, jan./jun. 2011, p. 297.
} 
Nesse sentido, Bortholo e Rocha" definem o assediador como "um indivíduo com personalidade narcisista que ataca a autoestima do outro, transferindo-lhe a dor e as contradições que não admite em si mesmo: o seu ego é tão grandioso quanto a sua necessidade de ser admirado e a sua falta de empatia".

Noutro viés, Gwendoline Auborg e Hélène de Moura ${ }^{38}$ compreendem que "não há um retrato padrão do assediador, sendo que nem sempre a pessoa que assedia tem uma personalidade perversa ou patológica”. Convergem nesse entendimento Bortholo e Rocha ${ }^{39}$, para quem: "não existe uma caricatura pronta e acabada de cada perfil. É um equívoco afirmar que todo assediador é simplesmente malvado". Também corroboram com esse pensamento Benevides e Rodrigues ${ }^{40}$, os quais concluem que "não existe estereótipo exato para o agressor do assédio moral laboral".

É precisamente nesta divergência entre caráter objetivo e subjetivo do assédio moral que o presente trabalho se propõe a atuar, ao reforçar o entendimento de que o assédio moral prescinde da perversidade, da intencionalidade do assediador em humilhar, perseguir, prejudicar o assediado. 0 assédio moral pode, inclusive, ser impessoal, revelar-se como normal política de gestão de pessoal, seja na empresa privada ou na administração pública. Para colaborar com referido entendimento, são utilizados conceitos desenvolvidos por Hannah Arendt, em especial sobre a "banalidade do mal", que se dá sempre que a pessoa se limita a ser mero "dente da engrenagem", sem questionamentos morais e sem empatia com o outro como pessoa.

\section{A “BANALIDADE DO MAL” E O ASSÉDIO MORAL NAS EMPRESAS}

0 artigo revisita o pensamento de Hannah Arendt sobre a "banalidade do mal", o que faz pela análise, em especial, da obra "Eichmann em Jerusalém: um relato sobre a banalidade do mal”, para, ao final, transpô-lo ao contexto empresarial, de maneira a compor o perfil de um

37 BORTHOLO, Julyana Moreira; ROCHA, Camila Oliveira da. Assédio moral nas relações de trabalho. Revista Terceiro Setor \& Gestão, v. 1, n. 9, 2015, p. 52.

${ }^{38}$ AUBORG, Gwendoline; DE MOURA, Hélène Apud THOMÉ, Candy Florencio. 0 assédio moral nas relações de emprego. São Paulo: LTr, 2009, p. 56.

39 BORTHOLO, Julyana Moreira; ROCHA, Camila Oliveira da. Assédio moral nas relações de trabalho. Revista Terceiro Setor \& Gestão, v. 1, n. 9, 2015, p. 57.

40 BENEVIDES, Sara Costa; RODRIGUES, Dayanna Gonçalves. Assédio moral no ambiente de trabalho: uma análise sobre os malefícios causados à vítima e suas consequências, bem como a atuação da Lei n. 13.185, de 6 de novembro de 2015, que institui o Programa de Combate à Intimidação Sistemática (bullying). Revista Científica FAGOC - Jurídica, v. 2, n. 1, 2016, p. 44. 
tipo de assediador, diferente do que se encontra, comumente, presente na pesquisa bibliográfica realizada.

$\mathrm{Na}$ obra acima mencionada, a autora reflete sobre a natureza do mal, tendo como pano de fundo o Nazismo, e como cenário o julgamento de Otto Adolf Eichmann, que foi designado para gerir a logística das deportações em massa dos judeus para os guetos e campos de extermínio das zonas ocupadas pelos alemães durante a Segunda Guerra Mundial.

Durante o julgamento, Hannah vê neste homem a figura de um burocrata cuja função da vida seria cumprir ordens, que teriam força de lei, de maneira que sequer precisariam ser escritas. Para Arendt" ${ }^{41}$ a premissa de que toda "pessoa normal" deve ter consciência da natureza de seus atos não é necessariamente verdadeira, pois, para ela, Eichmann era "normal", na medida em que não agia diferente do padrão dos que trabalhavam para o regime nazista; isto é, ele tinha uma conduta comum àqueles comprometidos com as ordens vigentes à época.

Não importa que as ordens que recebia fossem concernentes a "embarcar milhões de homens, mulheres e crianças para a morte, com grande aplicação e o mais meticuloso cuidado"42. Para Arendt" ${ }^{43}$, Eichmann é alguém que pensa de forma meramente técnica, descasada da ética, e assim o mal se apresenta como banal. Em depoimento, ele "não deixou nenhuma dúvida de que teria matado o próprio pai se houvesse recebido ordem nesse sentido", arremata Arendt.

Ainda na construção de um perfil do nazista, por ocasião do seu julgamento, Arendt o descreve como uma pessoa mediana, "normal”, nem burra, nem doutrinada, mas inteiramente incapaz de distinguir o certo do errado. E assim era desde os tempos de escola, uma pessoa medíocre, cujo ingresso na estrutura nazista não se deu por convicções ideológicas, mas pelo desejo de integrar-se e mostrar o seu valor.

A ambição do entrosamento e a limitação a um raciocínio que não seja diverso do silogismo das ordens ao caso concreto, o transformou em “dente da engrenagem", que ao se recusar em ver no outro uma pessoa, mas apenas objeto de normas superiores, foi capaz de ativamente colaborar com a eficiência de uma máquina criminosa. Ao se legitimar como "dente da engrenagem", em momento algum desenvolveu argumento crítico de valor sobre os seus atos.

\footnotetext{
41 ARENDT, Hannah. Eichmann em Jerusalém: um relato sobre a banalidade do mal. São Paulo: Companhia das Letras, 2004, p. 38.

42 ARENDT, Hannah. Eichmann em Jerusalém: um relato sobre a banalidade do mal. São Paulo: Companhia das Letras, 2004, p. 37.

43 ARENDT, Hannah. Eichmann em Jerusalém: um relato sobre a banalidade do mal. São Paulo: Companhia das Letras, 2004, p. 33-38.
} 
Arendt ${ }^{44}$ relata que Eichmann insistentemente se defendia das acusações afirmando que só poderia ser acusado de "ajudar e assistir" à aniquilação dos judeus, mas não de ter matado alguém, uma vez que, para tanto, teria de tê-lo feito com as próprias mãos. "O que ele fez estava feito, não pretendia negar; ao contrário, propunha 'ser enforcado publicamente como exemplo para todos os antissemitas da Terra'”.

Para Arendt ${ }^{45}$, Eichmann acreditava que tinha participado de um "esforço conjunto", na medida em que os judeus "desejavam emigrar" e ele ajudava, a todos, aos judeus e ao regime nazista, "os dois desejos coincidiam". Ela revela que ele assim afirmou no dia do julgamento: "eu nunca havia pensado numa coisas dessas, numa solução por meio da violência". Ainda na narrativa do julgamento, Hannah Arendt ressalta que, segundo o próprio réu, ele próprio "nunca pertenceu aos altos círculos do Partido; ele nunca ficava sabendo nada além do necessário para realizar um trabalho específico, limitado". No entanto, Arendt conclui que isso não the diminui a responsabilidade pelos danos causados às suas vítimas.

Mais adiante, há uma passagem especialmente esclarecedora do livro, na qual a autora ${ }^{46}$ comenta que Eichmann "nunca havia tomado uma decisão própria, que tinha sempre extremo cuidado em estar 'coberto' por ordens, não gostava nem de fazer perguntas e sempre solicitava 'diretivas'”. Na visão dela, ele se comportava sem nenhum tipo de questionamento moral de suas ações, ou das consequências destas, de maneira que a sua personalidade não correspondia a de um monstro criminoso, perverso, motivado pelo desejo de fazer o mal. A incapacidade dele de falar no julgamento estava intimamente relacionada com sua incapacidade de pensar, ou seja, de pensar do ponto de vista de outra pessoa ${ }^{47}$.

Em determinada parte do texto, Arendt ${ }^{48}$ afirma que ele não tinha a morte de 5 milhões de judeus na consciência. Para ela, ele inventava a autoria de alguns "feitos" relacionados ao Nazismo por ter compulsão de contar "vantagem", haja vista que parecia incomodado por ter passado a vida em atividades que não the tiravam do anonimato.

\footnotetext{
44 ARENDT, Hannah. Eichmann em Jerusalém: um relato sobre a banalidade do mal. São Paulo: Companhia das Letras, 2004, p. 33-71.

45 ARENDT, Hannah. Eichmann em Jerusalém: um relato sobre a banalidade do mal. São Paulo: Companhia das Letras, 2004, p. 60-99.

46 ARENDT, Hannah. Eichmann em Jerusalém: um relato sobre a banalidade do mal. São Paulo: Companhia das Letras, 2004, p. 61-109.

47 HEUER, Wolfgang. Ways of Narrating Memory: Hannah Arendt's "Eichmann in Jerusalem" and Steven Spielberg's "Schindler's List". Direito \& Práxis, Rio de Janeiro, v. 3, n. 1, 2012, p. 190.

48 ARENDT, Hannah. Eichmann em Jerusalém: um relato sobre a banalidade do mal. São Paulo: Companhia das Letras, 2004, p. 59-60.
} 
Nessa ordem de ideias, Arendt ${ }^{49}$ chama a atenção para o mal praticado por esse outro tipo de agressor, ao mencionar que, por mais monstruosos que fossem os atos de Eichmann, ele não era nem monstruoso nem demoníaco, e a única característica negativa que se podia detectar não se tratava de estupidez, mas de uma autêntica e curiosa incapacidade de pensar.

Por outro lado, essa forma de "banalização do mal” é uma ideia que já rondava a autora em suas obras anteriores, inclusive quando trata, especificamente, do trabalho, do labor e da vida ativa. No livro "Condição humana", quando $\operatorname{Arendt}^{50}$ faz a diferença entre a vida privada e a pública, no contexto dos gregos antigos, ela esclarece que a vida privada não é caracterizada pela intimidade, mas é um espaço no qual "os homens tornam-se inteiramente privados, isto é, privados de ver e ouvir os outros e privados de ser visto e ouvidos por eles".

O espaço no qual se pode ver o outro pelo olhar do outro e pelo outro ser visto mediante o próprio olhar é o público, qualificado pela política, onde ocorre a vida ativa. Vida ativa, aqui se destaca, porque o homem não apenas agiria premido pela necessidade e sob a dinâmica da causa e efeito que caracteriza o silogismo, mas porque ele se torna agente das relações: se põe e cria o novo.

Mas Arendt $^{51}$ fala que à medida que o trabalho e o consumo, caracterizados pelo comportamento e não pela ação, invadem o domínio público, não mais “poderá existir o verdadeiro domínio público, mas apenas atividades privadas exibidas à luz do dia. 0 resultado é aquilo que eufemisticamente é chamado de cultura de massas".

A engrenagem do trabalho e do consumo, a absorver cada vez mais a pessoa, vai habituando-a a ser "dente da engrenagem", vai aliciando-a para the ser cada vez mais útil e importante. Por conseguinte, perde-se a prática de olhar e se deixar olhar como pessoa: a função da vida passa a ser, cada vez mais, a integração à engrenagem social que se dá pelo trabalho e consumo, numa dinâmica em que o comportamento substitui, em escala crescente, a ação.

Por esse olhar de Hannah Arendt se pode olhar a instituição empregadora como engrenagem, que precisa de cada um de seus dentes, cada vez mais ajeitados e integrados ao seu funcionamento. Esta prática recepciona o assédio moral como forma de funcionamento institucional, que prescinde da intenção perversa do agressor.

\footnotetext{
49 ARENDT, Hannah. A dignidade da política: ensaios e conferências. Rio de Janeiro: Relume-Dumará, 1993, p. 145.

${ }^{50}$ ARENDT, Hannah. A Condição humana. Tradução: Roberto Raposo. 11. ed. Rio de Janeiro: Forense Universitária, 2010, p. 71.

${ }^{51}$ ARENDT, Hannah. A Condição humana. Tradução: Roberto Raposo. 11. ed. Rio de Janeiro: Forense Universitária, 2010, p. 106.
} 
No serviço público, por força do art. 116 , IV da Lei $\mathrm{n}^{\circ}$ 8.112, de 11 de dezembro de $1990^{52}$, são impostos deveres aos servidores, dentre os quais está o de obediência, vale dizer, o acatamento das ordens recebidas e sua imediata execução, tudo em razão da subordinação hierárquica. No entanto, o dever de obediência imposto ao servidor não é absoluto, ou seja, a obediência não deve ser "cega", haja vista que os servidores não estão obrigados a cumprir as ordens superiores quando elas são manifestamente ilegais. Ou seja, a máquina pública também se tem revelado campo fértil para a ocorrência da "banalidade do mal", embora, no último caso, a frustração esteja mais relacionada à perversidade do que à ausência de pensamento crítico na dinâmica da engrenagem.

Arendt $^{53}$ verifica que, no julgamento de Eichmann, foi reforçada essa ideia de que para serem desobedecidas às ordens têm de ser “manifestamente ilegais”. Porém, no caso, ser ilegal, naquele período, era desobedecer às ordens criminosas do regime nazista. Mas um "dente da engrenagem" não se questiona sobre a natureza criminosa da engrenagem: ele tão somente quer-lhe pertencer, da forma mais integrada possível. Desta forma, a associação do assédio moral a atos de crueldade, frieza, ambição, praticados por pessoas inteligentes, ardilosas e perversas, reflete de forma tímida a real escala do fenômeno.

A advertência arendtiana de que existe um mal diverso da perversão, que se dá pela banalidade de se ser acriticamente um "dente da engrenagem", bem o demonstra. Hannah Arendt insiste em direcionar o olhar para a agressão que passa desapercebida, que é asséptica, posto que não é pessoal, mas que integra a normal dinâmica de funcionamento da máquina. Aqui, o agressor não é sádico, mas apenas um bom e mediano funcionário, ao molde de Eichmann:

\begin{abstract}
Altura mediana, magro, meia-idade, quase calvo, dentes tortos e olhos míopes, que ao longo de todo o julgamento fica esticando o pescoço para olhar o banco de testemunhas (sem olhar nem uma vez para a plateia), que tenta desesperadamente, e quase sempre consegue, manter o autocontrole, apesar do tique nervoso que the retorce a boca, provavelmente desde muito antes do começo deste julgamento. ${ }^{54}$
\end{abstract}

O histórico de mediocridade e invisibilidade reforça a ambição em ser um dente concatenado ao todo da engrenagem. Eichmann, o descreve Arendt, "não era exatamente um

52 BRASIL. Lei $n^{\circ}$ 8.112, de 11 de dezembro de 1990. Diário Oficial da União. Poder Legislativo. Brasília, DF, 12 dez. 1990, Seção 1, p. 1.

53 ARENDT, Hannah. Eichmann em Jerusalém: um relato sobre a banalidade do mal. São Paulo: Companhia das Letras, 2004, p. 166.

54 ARENDT, Hannah. Eichmann em Jerusalém: um relato sobre a banalidade do mal. São Paulo: Companhia das Letras, 2004, p. 15. 
aluno dos mais estudiosos", enganava as pessoas sobre não ter conseguido terminar a escola secundária nem se formar na escola vocacional para engenharia, e atribuía seu insucesso às dificuldades financeiras de seu pai. Ela acrescenta ainda que ele "afirmava orgulhosamente ter sempre 'cumprido seu dever', obedecendo a todas as ordens como exigido em seu juramento", e que, no entanto, 'os poderosos' fizeram mau uso de sua 'obediência'”"55.

Não obstante a mediocridade, a vulgaridade preguiçosa do nazista, $\operatorname{Arendt}^{56}$ não o absolve de suas responsabilidades, ao afirmar que ele cometeu crimes não apenas " "contra o povo judeu', mas crimes contra a humanidade perpetrados no corpo do povo judeu". Para ela, tentar entender o agressor não é o mesmo que perdoá-lo.

Essa figura fantasmagórica, mesmo sem a intencionalidade do mal, mas antes o praticando mediante o orgulho da integração - tanto mais perfeita, melhor - ao funcionamento de uma máquina, é sim uma assediadora moral. Corrobora com essa afirmação a pesquisa bibliográfica sobre o perfil do assediador, em que foram encontrados registros cuja compreensão se aproxima muito do pensamento de Hannah Arendt, como o de Lecha ${ }^{57}$, para quem o assediador, normalmente, costuma ser obediente, disciplinado e dependente de seus superiores hierárquicos; não tem ou não se utiliza de seu senso crítico; gosta de fórmulas prontas; tendência à obstinação e a mentir a outrem, como a ele mesmo.

Outra leitura possível da "banalidade do mal" de Hannah Arendt é a realizada por Christophe Dejours, um estudioso da "banalização da injustiça social”, que:

Utiliza-se da análise de Hannah Arendt acerca da "banalidade do mal" no totalitarismo para teorizar sobre a banalização do mal na sociedade neoliberal atual. Segundo o autor, a diferença do totalitarismo e do neoliberalismo situa-se nos objetivos deste e daquele, mas o processo de banalização do mal é o mesmo, efetuado por meio do medo gerado diante de tal violência. Isso causa duas maneiras diversas de enfrentamento: a coletiva, por meio da negação das diferenças entre as pessoas, e a individual, mediante a clivagem entre sofrimento e injustiça. ${ }^{58}$

55 ARENDT, Hannah. Eichmann em Jerusalém: um relato sobre a banalidade do mal. São Paulo: Companhia das Letras, 2004, p. 15.

56 ARENDT, Hannah. Eichmann em Jerusalém: um relato sobre a banalidade do mal. São Paulo: Companhia das Letras, 2004, p. 17-268.

${ }^{57}$ LECHA, Gérard Apud THOME, Candy Florencio. $O$ assédio moral nas relações de emprego. São Paulo: LTr, 2009, p. 56.

${ }^{58}$ DEJOURS, Cristophe Apud THOME, Candy Florencio. 0 assédio moral nas relações de emprego. São Paulo: LTr, 2009, p. 26. 
Sobre o assunto, Thomé ${ }^{59}$ explica que a clivagem mencionada por Christophe Dejours é uma resposta individual ao assédio moral que faz com que o indivíduo crie dois mundos, um interior e outro exterior. No interior, apresenta-se como uma pessoa sensível e moral, já no exterior (normalmente no trabalho), age de forma despersonalizada e com distanciamento dos fatos que ocorrem à sua volta.

Nesse cenário, Bruna Meurer e Marlene Neves Strey ${ }^{60}$ afirmam que não há como precisar o perfil de agressores e vítimas, pois a própria conjuntura do trabalho atual, somada à crise ética, social e ao desgaste psicoemocional, são fatores que aumentam a adoção desses comportamentos hostis. Entretanto, Pinheiro ${ }^{61}$ ensina que "o grande perigo que se corre ao não facultar aos seres humanos a capacidade de ação e julgamento, a exemplo do caso Eichmann, é se convencer que o mal que fazemos ao outro não nos diz respeito".

Nessa perspectiva, no desfecho da obra, Arendt chama a atenção para uma das grandes questões morais de todos os tempos, perfeitamente aplicável ao tema do assédio moral, que é a natureza e o juízo humano:

os seres humanos devem ser capazes de diferenciar o certo do errado mesmo quando tudo o que têm para guia-los seja apenas seu próprio juízo, que, além do mais, pode estar inteiramente em conflito com o que eles devem considerar como opinião unânime de todos a sua volta. ${ }^{62}$

Seguindo um raciocínio sistêmico, Dejours ${ }^{63}$ pondera que "as relações de trabalho, dentro das organizações, frequentemente, despojam o trabalhador de sua subjetividade, excluindo o sujeito e fazendo do homem uma vítima do seu trabalho". Acompanham esse pensamento, Bortholo e Rocha ${ }^{64}$ ao atribuírem as causas do assédio moral no trabalho às pessoas, à organização e ao meio em que este se dá, como resultado da interação entre estes e outros

\footnotetext{
${ }^{59}$ THOME, Candy Florencio. $O$ assédio moral nas relações de emprego. São Paulo: LTr, 2009, p. 26.

60 MEURER, Bruna; STREY, Marlene Neves. Problematizando as práticas psicológicas no modo de compreender o fenômeno assédio moral. Revista Psicologia: Ciência e Profissão, Brasília, v. 2, n. 32, 2012, p. 468.

61 PINHEIRO, Antonio dos Santos. A violência na contramão do poder: a atualidade do pensamento de Hannah Arendt. Disponível em: http://www.sbsociologia.com.br/portal/index.php?option=com_docman\& task $=$ doc_download\&gid=22\&ltemid=171. Acesso em: 16 ago. 2018.

62 ARENDT, Hannah. Eichmann em Jerusalém: um relato sobre a banalidade do mal. São Paulo: Companhia das Letras, 2004, p. 318.

${ }^{63}$ DEJOURS, Cristophe Apud RODRIGUES, Patrícia Ferreira; ALVARO, Alex Leandro Teixeira; RONDINA, Regina. Sofrimento no trabalho na visão de Dejours. Revista Científica Eletrônica de Psicologia, v. 7, n. 1, nov. 2006, p. 4.

64 BORTHOLO, Julyana Moreira; ROCHA, Camila Oliveira da. Assédio moral nas relações de trabalho. Revista Terceiro Setor \& Gestão, v. 1, n. 9, 2015, p. 59.
} 
elementos. Arremata a temática Thome ${ }^{65}$ ao afirmar que o que deve determinar a existência de assédio moral nas relações de emprego é, portanto, a existência ou não de degradação psicológica das condições de trabalho e não a intencionalidade e premeditação do sujeito ativo.

Ao pensar em soluções para o problema, Heloani ${ }^{66}$ comenta medidas que podem e devem ser tomadas para se coibir, ou até mesmo erradicar, o assédio moral:

Do ponto de vista das empresas, a criação e a aplicação de códigos de ética é certamente uma conquista importante, embora não suficiente. Além de tais códigos, poderiam ser criados mecanismos para dar ao funcionário agredido o direito de denunciar a agressão de que tenha sido vítima, por escrito e sigilosamente. Assim, a vítima poderia utilizar caixas postais ou urnas para ter seu anonimato garantido. Mas é preciso também rever as condições que determinam o exagerado ambiente de competição. Isso representaria um passo efetivo no processo de humanização do trabalho. Em outras palavras, a discussão do assédio moral deve levar as pessoas a refletirem sobre a condição sistêmica da questão: não se trata de problema individual, mas de um problema que envolve interações sociais complexas e a conquista de direitos fundamentais.

Mas a questão é que o entendimento majoritariamente aceito na literatura que trabalha o perfil do agressor do assédio moral no trabalho não converge com as ideias de Hannah Arendt, pois, para ela, dentre os agressores nazistas poderia até haver um torturador particularmente pervertido, tirando prazer do sofrimento, mas, no geral, eram homens como os outros, colocados em condições de violência generalizada, de banalização do sofrimento. Logo, na obra “Eichmann em Jerusalém", Hannah Arendt não estava desculpando torturadores, estava apontando a dimensão real do problema, a sistêmica, haja vista que, por vezes, a monstruosidade não está na pessoa, e sim no sistema. Um sistema que permite que homens banais façam o mal (tortura, humilhação etc). Portanto, há sistemas que banalizam o mal, ao conviverem com naturalidade com a prática de várias formas de violência, sobretudo a moral, a qual, por chamar menos atenção do que a física, tem o combate negligenciado.

Conforme Pertuzatti e Almeida ${ }^{67}$, sempre haverá novas versões e perspectivas de análise sobre a temática do assédio moral nas empresas. Logo, por essas e por outras razões, tais como o grau de sofrimento das vítimas de assédio moral decorrente do trabalho, o estudo conduz a um repensar sobre o que se configura como assédio moral e como perfil assediador, pois devem ser alargadas as hipóteses, sob pena de graves ilícitos não serem devidamente rechaçados.

\footnotetext{
65 THOME, Candy Florencio. 0 assédio moral nas relações de emprego. Revista do Tribunal Regional do Trabalho da $15^{\text {a }}$ Região, Campinas, n. 31, 2007, p. 213.

${ }^{66}$ HELOANI, Roberto. Violência Invisível. RAE Executivo, v. 3, n. 2, pp. 57-61, ago./out. 2003, p. 61.

67 PERTUZATTI, Dirceu; ALMEIDA, Maria de Lourdes Pinto de. Assédio moral na relação de emprego no Brasil do século XXI: por um resgate da dignidade da pessoa humana. Revista da Faculdade de Direito UFPR, Curitiba, v. 1, n. 43, 2005, p. 5.
} 
O que diferencia o homem de um “dente da engrenagem", ainda na esteira dos ensinamentos arendtianos, frise-se, é a sua capacidade de ser pessoa: de olhar o outro pelo olhar do outro e de se deixar olhar pelo outro mediante o próprio olhar. Esse é um dado basilar da dignidade humana, que deve ser protegido, inclusive, em relações privadas, crescentemente tomadas pelo assomo da produção e do consumo.

\section{CONCLUSÃO}

As empresas muitas vezes se utilizam do argumento de que são geradoras de emprego e renda para relativizarem o combate ao assédio moral praticado no ambiente de trabalho. Nesse contexto, o artigo traça um paralelo entre o mal relatado por Hannah Arendt na obra "Eichmann em Jerusalém" e o mal causado pelo assédio moral laboral.

Hannah Arendt narra o que assistiu presencialmente no julgamento de Adolf Eichmann, um dos principais responsáveis pela deportação dos judeus europeus durante o Holocausto, e contextualiza historicamente neste período uma narrativa das atividades de Eichmann que, em várias passagens, poderia ser confundida com transporte de cargas, haja vista que, por vezes, menciona-se a troca de carregamento por dinheiro ou por caminhões, mas, na verdade, eram milhares de seres humanos sendo transportados para guetos ou para campos de concentração que entraram para as terríveis estatísticas dos extermínios que aconteceram na $2^{\mathrm{a}}$ Guerra Mundial. Durante o julgamento de Eichmann, ela constata que nem todos que participaram dos crimes de guerra tinham perfil monstruoso.

0 artigo não é mais uma retrospectiva dos horrores que aconteceram durante esse período, mas sim uma análise relacionada à leitura que a autora faz acerca da "banalidade do mal". Traz-se a "banalidade do mal" para a realidade negativa que o assédio moral repercute nas empresas. A "banalidade do mal" revelada ao mundo por Arendt é a lição que se pode aprender com o julgamento de Eichmann em Jerusalém, a qual desafia as palavras e os pensamentos, pois consiste em tomar como comum o que não é normal, algo que é moralmente estabelecido como mal.

Em outras palavras, Eichmann, no julgamento, argumentou que não tinha autoridade para decidir quem ia morrer ou quem ia viver e assim ele se eximia de se sentir culpado, já que nunca executou quem quer que fosse, embora muitas vezes tenha transportado pessoas para serem mortas. Ele afirmava que não sabia se aquelas pessoas realmente seriam executadas, pois poderiam até sobreviver, como às vezes acontecia. 
A figura de Eichmann se apresenta, diante do olhar de Arendt, como um funcionário pronto a obedecer a qualquer voz imperativa, incapaz de refletir sobre seus atos. Nessa perspectiva, o artigo reverbera o perfil de um tipo de assediador moral que nem sempre é alguém que age imbuído da vontade de fazer o mal, mas não é menos culpado pelo mal que eventualmente cause. Na pesquisa bibliográfica realizada, constatou-se que esse perfil de agressor é pouco considerado por aqueles que estudam o fenômeno do assédio moral nas empresas.

O mal encontrado em Eichmann é banal porque, além de não serem apresentadas explicações convincentes para seus atos, não há nenhuma das motivações comumente esperadas: não resulta de sadismo, mas apenas de se legitimar como dente da engrenagem. 0 mal que não é radicado, isto é, que não tem raiz, que resulta da displicência moral em se aprimorar no comportamento social que é exigido ao agente. Grande parte da literatura que estuda o assédio moral nas empresas o associa a condutas de alguém perverso, no entanto, tomando como base o ensinamento de Hannah Arendt, o artigo se propõe a contribuir para identificação do assédio moral quando cometido por alguém que não se questionou sobre o que estava fazendo, uma vez que a função da vida seria bem concatenar-se à engrenagem à qual pertence.

Logo, o trabalho volta a atenção para pessoas perpetradoras improváveis do mal, mas que ainda assim são capazes de causar um mal extremo, seja num contexto de guerra, seja num ambiente de trabalho. Ao desposar a pessoa da sua pessoalidade para torná-la um dente da engrenagem, o que faz um outro dente da engrenagem que o quer ser da forma mais eficiente possível, embora sem pretensão de prejudicar e ferir mas sem, quanto a tanto, se importar, um grande mal se está fazendo, e o direito não pode ficar inerte.

As empresas, por sua vez, devem examinar o assédio moral por esta lente: não apenas como um mal que the é estranho, pois pessoal ao agente sádico, mas um mal pelo qual ela pode ser responsável ao adotar uma dinâmica de funcionamento cuja produtividade seja requestada sem responsabilidade pela pessoalidade do trabalhador.

\section{REFERÊNCIAS}

ARENDT, Hannah. A condição humana. Tradução: Roberto Raposo. Rio de Janeiro: Forense Universitária, 2010.

ARENDT, Hannah. A dignidade da política: ensaios e conferências. Rio de Janeiro: Relume-Dumará, 1993. 
ARENDT, Hannah. Eichmann em Jerusalém: um relato sobre a banalidade do mal. São Paulo: Companhia das Letras, 2004.

BARRETO, Margarida. Violência, saúde e trabalho: uma jornada de humilhações. São Paulo: EDUC/FAPESP, 2003.

BARRETO, Margarida; HELOANI, Roberto. Violência, saúde e trabalho: a intolerância e o assédio moral nas relações laborais. Serv. Soc. Soc. São Paulo, v. 123, n. 1, p. 544-561, jul./set. 2015.

BAUMAN, Zygmunt. Modernidade líquida. Rio de Janeiro: Jorge Zahar Editor, 2000.

BENEVIDES, Sara Costa; RODRIGUES, Dayanna Gonçalves. Assédio moral no ambiente de trabalho: uma análise sobre os malefícios causados à vítima e suas consequências, bem como a atuação da Lei n. 13.185, de 6 de novembro de 2015, que institui o Programa de Combate à Intimidação Sistemática (bullying). Revista Científica FAGOC - Jurídica, v. 2, n. 1, p. 41-53, 2016.

BORTHOLO, Julyana Moreira; ROCHA, Camila Oliveira da. Assédio moral nas relações de trabalho. Revista Terceiro Setor \& Gestão, v. 1, n. 9, p. 48-59, 2015.

BRASIL. Constituição Federal. Brasília: Senado Federal, 1988. Disponível em:

https://www.planalto.gov.br/ccivil_03/constituicao/constituicao.htm. Acesso em: 17 ago. 2018.

BRASIL. Lei $n^{\circ} 8.112$ de 11 de dezembro de 1990. Dispõe sobre o regime jurídico dos servidores públicos civis da União, das autarquias e das fundações públicas federais. In: Diário Oficial da República Federativa do Brasil. Brasília, DF, 12 dez. 1990. Disponível em:

http://www.planalto.gov.br/ccivil_03/Leis/L8112cons.htm. Acesso em: 17 ago. 2018.

CARDOSO, Guilherme Augusto; ALMEIDA, Victor Hugo de. Assédio moral na administração pública: uma visão crítica da jurisprudência brasileira. Revista Eletrônica do Curso de Direito da UFSM, Santa Maria, RS, v. 11, n. 1, p. 320-347, 2016. ISSN 1981-3694. Disponível em:

https://periodicos.ufsm.br/revistadireito/article/view/21297/pdf. Acesso em: 17 ago. 2018.

DALLEGRAVE NETO, José Afonso. Responsabilidade civil no direito do trabalho. São Paulo: LTr, 2005.

ELGENNENI, Sara Maria de Melo; VERCESI, Cristiane. Assédio moral no trabalho: implicações individuais, organizacionais e sociais. Revista Psicologia: Organizações e Trabalho. Brasília, v. 1, n. 9, p. 68-85, jan./jun. 2009.

FERREIRA, Hádassa Dolores Bonilha. Assédio moral nas relações de trabalho. Campinas: Russell, 2004.

FREITAS, Maria Ester de. Assédio moral e assédio sexual: faces do poder perverso nas organizações. ERA, v. 2, n. 41, abr./jun. 2001.

FREITAS, Maria Ester de. Quem paga a conta do assédio moral no trabalho?. RAE-eletrônica, v. 1, n. 6, jan./jun. 2007.

FREITAS, Maria Ester de et al. Assédio Moral no Trabalho. São Paulo: Cengage Leaning, 2008. 
GLINA, Débora Miriam Raab; SOBOLL, Lis Andreia. Intervenções em assédio moral no trabalho: uma revisão da literatura". Revista Brasileira de Saúde Ocupacional. São Paulo, v. 126, n. 37, p. 269283, 2012.

GOLDSCHMIDT, Rodrigo; CRUSARO, Jusara. Assédio moral nas relações de trabalho. Pensar. Fortaleza, v. 1, n. 16, p. 292-310, jan./jun. 2011.

GUEDES, Márcia Novaes. Terror psicológico no trabalho. São Paulo: LTr, 2004.

HELOANI, Roberto. Violência Invisível. RAE Executivo, v. 3, n. 2, p. 57-61, ago./out. 2003.

HELOANI, Roberto. Assédio Moral: um ensaio sobre a expropriação da dignidade no trabalho. RAEeletrônica, v. 1, n. 3, p. 1-8, jan./jun. 2004.

HEUER, Wolfgang. Ways of Narrating Memory: Hannah Arendt's "Eichmann in Jerusalem" and Steven Spielberg's "Schindler's List". Direito \& Práxis, Rio de Janeiro, v. 3, n. 1, p. 184-199, 2012.

HIRIGOYEN, Marie-France. Assédio moral: a violência perversa no cotidiano. Rio de Janeiro: Bertrand Brasil, 2002.

HIRIGOYEN, Marie-France. Mal-estar no trabalho: redefinindo o assédio moral. Rio de Janeiro: Bertrand Brasil, 2006.

MENDONÇA, Gisele Galatti et al. Assédio Moral: práticas coercitivas nas relações de trabalho. Revista Eletrônica de Ciências Empresariais, v. 2, n. 1, p. 1-9, jan./jul. 2008.

MEURER, Bruna Meurer; STREY, Marlene Neves. Problematizando as práticas psicológicas no modo de compreender o fenômeno assédio moral. Revista Psicologia: Ciência e Profissão, Brasília, v. 2, n. 32, p. 452-471, 2012.

MORAES, Patrícia Regina de Moraes et al. A Configuração do Assédio Moral nas Relações Trabalhistas. Revista Ampla de Gestão Empresarial, Registro, São Paulo, v. 1, n. 3, p. 195-214, abr. 2014.

OLIVEIRA, Paulo Eduardo Vieira. O dano pessoal no trabalho. São Paulo: LTr, 2002.

OLIVEIRA, Sebastião Geraldo de. Indenizações por acidente do trabalho ou doença ocupacional. São Paulo: LTr, 2006.

PELI, Paulo; TEIXEIRA, Paulo. Assédio moral: uma responsabilidade corporativa. São Paulo: Ícone, 2006.

PERTUZATTI, Dirceu; ALMEIDA, Maria de Lourdes Pinto de. Assédio moral na relação de emprego no Brasil do século XXI: por um resgate da dignidade da pessoa humana. Revista da Faculdade de Direito UFPR, Curitiba, v. 1, n. 43, p. 1-16, 2005.

PINHEIRO, Antonio dos Santos. A violência na contramão do poder: a atualidade do pensamento de Hannah Arendt. Disponível em:

http://www.sbsociologia.com.br/portal/index.php?option=com_docman\&task=doc_download\&gid=22 \&ltemid=171. Acesso em: 17 ago. 2018. 
RODRIGUES, Patrícia Ferreira; ALVARO, Alex Leandro Teixeira; RONDINA, Regina. Sofrimento no trabalho na visão de Dejours. Revista Científica Eletrônica de Psicologia, v. 7, n. 1, p. 1-8, nov. 2006.

SARLET, Ingo Wolfgang. A eficácia dos direitos fundamentais. Porto Alegre: Livraria do Advogado, 2001.

SILVA, Jorge Luiz de Oliveira da. Assédio moral no ambiente de trabalho. Rio de Janeiro: Jurídica do Rio de Janeiro, 2005.

SILVA, Leda Maria Messias da. Poder diretivo do empregador, emprego decente e direitos da personalidade. Revista Jurídica Cesumar, v. 1, n. 6, p. 267-281, 2006.

THOME, Candy Florencio. 0 assédio moral nas relações de emprego. Revista do Tribunal Regional do Trabalho da $15^{\text {a }}$ Região, Campinas, n. 31, p. 209-228, 2007. Disponível em:

https://juslaboris.tst.jus.br/bitstream/handle/1939/105292/2007_thome_candy_assedio_moral.pdf? sequence=1\&isAllowed=y. Acesso em: 17 ago. 2018.

THOME, Candy Florencio. 0 assédio moral nas relações de emprego. São Paulo: LTr, 2009.

Recebido em: 31.01.2018 / Revisões requeridas em: 09.07.2018 / Aprovado em: 30.08.2018 / Publicado em: 06.05.2019

\section{COMO FAZER REFERÊNCIA AO ARTIGO (ABNT):}

SIQUEIRA, Natercia Sampaio; MEMÓRIA, Caroline Viriato. A "banalidade do mal" nas empresas: revisitando Hannah Arendt. Revista Eletrônica do Curso de Direito da UFSM, Santa Maria, RS, v. 14, n. 2, e31009, maio./ago. 2019. ISSN 1981-3694. DOI: http://dx.doi.org/10.5902/1981369431009. Disponível em: https://periodicos.ufsm.br/revistadireito/article/view/31009 Acesso em: dia mês. ano.

Direitos autorais 2019 Revista Eletrônica do Curso de Direito da UFSM

Editores responsáveis: Rafael Santos de Oliveira e Angela Araujo da Silveira Espindola

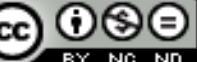

Este obra está licenciado com uma Licença Creative Commons Atribuição-NãoComercial-SemDerivações 4.0 Internacional.

\section{SOBRE AS AUTORAS}

\section{NATÉRCIA SAMPAIO SIQUEIRA}

Possui graduação em Direito pela Universidade Federal do Ceará (1998), Mestrado em Direito Tributário pela Universidade Federal de Minas Gerais (2002) e Doutorado em Direito Constitucional pela Universidade de Fortaleza (2011). É Pósdoutoranda em Direito econômico na Faculdade de Direito da Universidade de Lisboa, Professora do curso de Pós-graduação (mestrado e doutorado) em direito Constitucional da Universidade de Fortaleza e membro do CELA. Atua na área da Teoria da Justiça e Justiça Tributária. É procuradora Fiscal do Município de Fortaleza.

\section{CAROLINE VIRIATO MEMÓRIA}

Advogada e servidora do Ministério da Ciência, Tecnologia, Inovações e Comunicacõos - MCTIC. Doutoranda em Direito Constitucional pela Universidade de Fortaleza - UNIFOR. Mestre em Administração Pública pela Universidade de Brasília UnB. Especialista em Direito do Trabalho pela Universidade Cândido Mendes - RJ. Especialista em Direito Tributário pela Universidade de Fortaleza - UNIFOR. Graduada em Direito pela Universidade de Fortaleza - UNIFOR. (Texto informado pelo autor) 